\title{
Effect of the prolactin-release inhibitor quinagolide on lactating dairy cows
}

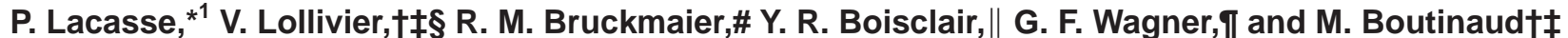 \\ *Dairy and Swine Research and Development Centre, Agriculture and Agri-Food Canada, PO Box 90 STN Lennoxville, Sherbrooke, Quebec, \\ Canada J1M $1 Z 3$ \\ †INRA, UMR1080 Production du lait, F-35000 Rennes, France \\ $\ddagger$ Agrocampus Ouest, UMR1080 Production du lait, F-35000 Rennes, France \\ §Université européenne de Bretagne, F-35000 Rennes, France \\ \#Veterinary Physiology, Vetsuisse Faculty, University of Bern, Switzerland \\ ||Department of Animal Science, Cornell University, Ithaca, NY 14853 \\ IDepartment of Physiology and Pharmacology, Faculty of Medicine and Dentistry, University of Western Ontario, London, Ontario, \\ Canada N6A 5C1
}

\section{ABSTRACT}

In most mammals, prolactin (PRL) is essential for maintaining lactation, and yet the short-term suppression of PRL during established lactation by bromocriptine has produced inconsistent effects on milk yield in cows and goats. To assess the effect of the long-term inhibition of PRL release in lactating dairy cows, 5 Holstein cows in early lactation received daily intramuscular injections of $1 \mathrm{mg}$ of the PRL-release inhibitor quinagolide for 9 wk. Four control cows received the vehicle (water) only. During the last week of the treatments, one udder half was milked once a day $(1 \times)$ and the other twice a day $(2 \times)$. Blood samples were harvested at milking in wk $-1,1,4$, and 8 . The daily injections of quinagolide reduced milking-induced PRL release but not the basal PRL concentration. Quinagolide induced a faster decline in milk production, which was about $5.3 \mathrm{~kg} / \mathrm{d}$ lower in the quinagolidetreated cows during the last 4 wk of treatment. During wk 9 , the inhibition of milk production by quinagolide was maintained in the udder half that was milked $2 \times$ but not in the half milked $1 \times$. Milk production was significantly correlated with the quantity of PRL released at milking. Quinagolide did not affect the release of oxytocin at milking. Serum concentration of insulinlike growth factor-1 was not affected by treatment or correlated with milk production. Serum concentrations of leptin and the calciotropic hormone stanniocalcin were not affected by the treatment. In conclusion, the chronic administration of the PRL-release inhibitor quinagolide decreases milk production in dairy cows. The effect is likely the result of the reduced release of milking-induced PRL and is modulated at the level of the gland by milking frequency.

Received June 26, 2010.

Accepted November 17, 2010.

${ }^{1}$ Corresponding author: Lacassep@agr.gc.ca
Key words: lactation, milking frequency, leptin, stanniocalcin

\section{INTRODUCTION}

As its name implies, prolactin (PRL) is the most important hormone for the control of lactation. This hormone is known to be mammogenic and lactogenic in both monogastric and ruminant mammals. In most mammals, the suppression of PRL strongly inhibits lactation (Taylor and Peaker, 1975; Flint and Gardner, 1994). However, the involvement of PRL in the control of ruminant lactation is less clear. Plaut et al. (1987) did not observe any increase in milk production by cows when PRL was injected for $14 \mathrm{~d}$ in early lactation, although another study reported a limited increase in goats (Knight, 1993). The short-term administration before parturition of bromocriptine, a dopamine agonist that suppresses PRL release, reduced postpartum milk production in goats (Forsyth and Lee, 1993) and cows (Akers, 2002). However, similar treatments applied during established lactation have produced small or no effects on milk yield (Knight, 1993).

Milking and suckling induce an important increase in PRL in the blood of the female. This effect is not related to the milk harvest itself, as it can be induced in nonlactating animals by nipple stimulation (Akers and Lefcourt, 1983). This neuroendocrine reflex is poorly understood, but it is known that the amount of PRL released decreases as lactation advances (Fuchs et al., 1984) and that suckling is more efficient than milking at inducing the reflex (Lupoli et al., 2001). Although the basal PRL level is not clearly associated with the amount of milk produced, milking-induced PRL release is correlated with the level of milk production in both cows and mice (Koprowski and Tucker, 1973; Akers, 2002). In addition, antiapoptotic effects of PRL have been reported in the mammary gland of rodents (Travers et al., 1996; Flint et al., 2006) and 
bovine mammary explants (Accorsi et al., 2002). It is therefore possible that PRL, especially milking-induced PRL, plays an important role in lactation persistency by limiting the loss of secretory cells and maintaining cell differentiation.

Quinagolide is a compound that binds specifically to the lactotroph dopamine D2 receptor, decreasing the synthesis and release of PRL (Brownell, 1996). Unlike the ergot alkaloid bromocriptine, which was used in early studies on PRL action in cows, quinagolide has little affinity for serotonin and $\alpha$-adrenergic binding sites (Brownell, 1998). In animal models, quinagolide has a longer half-life, has fewer side effects, and is 200 times more potent than bromocriptine in terms of inhibiting lactation (Brownell, 1998). Therefore, the objective of this study was to evaluate whether PRL is galactopoietic in the bovine by chronically inhibiting its secretion with quinagolide.

\section{MATERIALS AND METHODS}

The ethical aspects of the care of the animals used in this study were in compliance with the relevant guidelines and licensing requirements, as defined by the French Ministry for Agriculture in accordance with French regulations (Decree No. 2001-464, May 29, 2001).

\section{Experimental Design}

Ten multiparous Holstein cows averaging $62 \mathrm{~d}$ in milk were used in this study. The cows were housed at the Méjusseaume experimental dairy farm of INRA UMR1080 Production du lait (Le Rheu, France). Cows were fed ad libitum with a diet containing (on a DM basis) $65 \%$ corn silage, $15 \%$ alfalfa silage, $18.5 \%$ supplement, and $1.5 \%$ mineral supplement. Feed intake and milk production were recorded daily during the last $2 \mathrm{wk}$ before the initiation of the treatments (pretreatment period) and during the treatment period. Each cow's BW was determined in wk $-2,1,3,6$ and 8 (relative to treatment initiation). During the pretreatment period and the first $8 \mathrm{wk}$ of the treatments, all quarters were milked twice daily.

During the 9 -wk treatment period, 5 of the cows received daily (at $1000 \mathrm{~h}$ ) intramuscular injections of $1 \mathrm{mg}$ quinagolide (Ferring, Wallisellen, Switzerland), and the other 5 received water injections (control treatment). One control cow was treated for mastitis. She was removed from the experiment and her data were discarded. During the last treatment week, differential milking was applied, with one udder half milked once a day $(\mathbf{1} \times)$ and the other twice a day $(\mathbf{2} \times)$.
Milk yield was recorded at each milking. During the differential milking, milk yield was measured and collected by udder halves. Individual milk samples were collected 3 times a week to determine milk composition. In addition, aliquots of the milk samples were skimmed by centrifugation $\left(15 \mathrm{~min}, 1,000 \times g, 4^{\circ} \mathrm{C}\right)$ and frozen once a week. Those samples were used to determine levels of milk gelatinase [matrix metalloproteinase (MMP)-2 and MMP-9] activity, BSA, and stanniocalcin-1 (STC-1).

To determine hormonal release, jugular blood samples were taken in wk -1, 1, 4 and 8. A silastic catheter (Silclear medical-grade silicone tubing, i.d. $1.02 \mathrm{~mm}$, o.d. $2.16 \mathrm{~mm}$; Degania Silicone, Degania Bet, Israel) was inserted into a jugular vein of each cow the day before the first blood sampling and remained there for the duration of the study. The blood samples were taken before and during a.m. milking (at $-2,1,2,5,10$, and 15 min after milking machine attachment) using Monovette syringes coated with EDTA and sodium heparin (Sarstedt, Nümbrecht, Germany). An additional sample was collected weekly $1 \mathrm{~h}$ after the milking into heparincoated tubes to determine concentrations of glucose, lactose, urea, NEFA, leptin, and STC-1. Plasma was separated by centrifugation at $4^{\circ} \mathrm{C}$ and $3,000 \times g$ for $15 \mathrm{~min}$ and then stored at $-20^{\circ} \mathrm{C}$ for later analysis.

\section{Analyses}

Milk protein and fat contents were determined by a commercial laboratory using infrared analysis (Lillab, Châteaugiron, France). Milk lactose and casein were determined once a week as described by Hurtaud et al. (1993). The BSA concentration of the milk was determined as described by Tremblay et al. (2009). Milk gelatinase activity was determined using gelatin zymography, with zymograms performed as described by Tremblay et al. (2009).

Plasma PRL concentration was measured using an indirect competitive ELISA (Kollmann et al., 2008). The intraassay variability was $<5 \%$ and the interassay variability was $<12 \%$. Plasma concentration of oxytocin was measured using the enzyme immunoassay method (Marnet et al., 1994). The detection limit was $7 \mathrm{pg} / \mathrm{mL}$, the intraassay CV was 7\%, and the interassay CV was 8\%. Plasma leptin was determined using RIA (Ehrhardt et al., 2000). The intraassay CV was $5.6 \%$, and the interassay CV was $2.9 \%$. Milk and plasma concentrations of STC-1 were determined using RIA as described by De Niu et al. (2000) and validated for bovine STC-1 (Paciga et al., 2002) with inter- and intraassay CV of 8.6 and $7.5 \%$, respectively. Plasma (from EDTA-coated tubes) concentration of IGF-1 was determined by RIA (Vicari et al., 2008). 
Table 1. Effect of the injection of water (control; $\mathrm{n}=4)$ or quinagolide $(1 \mathrm{mg} / \mathrm{d} ; \mathrm{n}=5)$ for 8 wk on milk composition in dairy cows ${ }^{1}$

\begin{tabular}{|c|c|c|c|c|c|}
\hline \multirow[b]{2}{*}{ Item } & \multicolumn{2}{|c|}{ Treatment (Trt) } & \multirow[b]{2}{*}{ SEM } & \multicolumn{2}{|c|}{$P$-value } \\
\hline & Control & Quinagolide & & Trt & Trt $\times$ time \\
\hline Fat $(\%)$ & 4.03 & 4.18 & 0.67 & $\mathrm{NS}^{2}$ & NS \\
\hline Fat $(\mathrm{kg} / \mathrm{d})$ & 1.52 & 1.38 & 0.25 & 0.01 & NS \\
\hline Protein (\%) & 3.07 & 3.16 & 0.63 & NS & NS \\
\hline Protein $(\mathrm{kg} / \mathrm{d})$ & 1.15 & 1.04 & 0.32 & 0.04 & NS \\
\hline Lactose $(\mathrm{kg} / \mathrm{d})$ & 1.78 & 1.54 & 0.60 & 0.03 & NS \\
\hline Casein $(\%)$ & 2.17 & 2.27 & 0.61 & NS & NS \\
\hline
\end{tabular}

Plasma (from heparin-coated tubes) concentrations of glucose, urea, NEFA, and lactose were measured on a multiparameter analyzer (KONE Instruments Corp., Espoo, Finland). Commercial kits for glucose (kit glucose hexokinase, Diagnostics, Meylan, France), NEFA (NEFA C test, Wako, Oxoid, Davdilly, France), urea (ref. 11703, Thermo Electron, Cergy-Pontoise, France). and lactose (kit for lactose/D-galactose; Roche Diagnostics, Meylan, France) were used.

\section{Statistical Analyses}

Data were analyzed by ANOVA using the MIXED procedure of SAS (SAS Institute Inc., Cary, NC) with the REPEATED statement. Time was used as a repeated effect, and cow(treatment) was used as the subject. For all variables except oxytocin, the data obtained during the pretreatment period were averaged and used as a covariate. The amounts of PRL and oxytocin released into the blood at milking were calculated by determining the areas under the curves. Differential milking data from the last $3 \mathrm{~d}$ of the period were averaged and analyzed by using the MIXED procedure with a REPEATED statement. Quinagolide treatment and milking frequency were the main effects and cow(treatment) was used as the subject. The effect of quinagolide treatment within milking frequency was evaluated with the slice option on the interaction term in the LSMEANS statement. The relationship between several parameters was evaluated using the CORR procedure of SAS. Differences were considered statistically significant when $P<0.05$.

\section{RESULTS}

The amount of PRL released at milking was reduced by quinagolide $(P<0.05)$. In wk 1,4 , and 8 , respectively, the amount released averaged 32,12 , and $20 \%$ of the wk -1 amount in the quinagolide-treated cows and 104,83 , and $73 \%$ of the wk -1 amount in the control cows. The basal PRL concentration was not affected by the quinagolide treatment.

Milk production declined faster in quinagolide than control cows $(P<0.05$; Figure 1$)$. Milk production of quinagolide-treated cows was $5.3 \mathrm{~kg} / \mathrm{d}$ less than that of control cows during the last 4 wk of treatment. Milk fat content was not affected by treatment (Table 1). Milk protein content increased by $10 \%$ during the experiment $(P<0.001)$ but was not affected by treatment (Table 1). Accordingly, milk fat and protein yields were decreased $(P<0.01$ and 0.05 , respectively) in the quinagolide-treated animals. Lactose content of the milk was similar for both groups of animals for the first $4 \mathrm{wk}$, but was reduced $(P<0.05)$ in the quinagolidetreated animals in wk 5, 6, and 7 (Figure 2). Lactose yield was also reduced by the quinagolide treatment $(P$ $<0.05$; Table 1). Casein content of the milk was not affected by the treatment.

The cows treated with quinagolide ate less than the control cows $(P<0.05)$, with DMI averaging $22.8 \pm$ 0.5 and $21.1 \pm 0.4 \mathrm{~kg} / \mathrm{d}$ for the control and quinagolide-

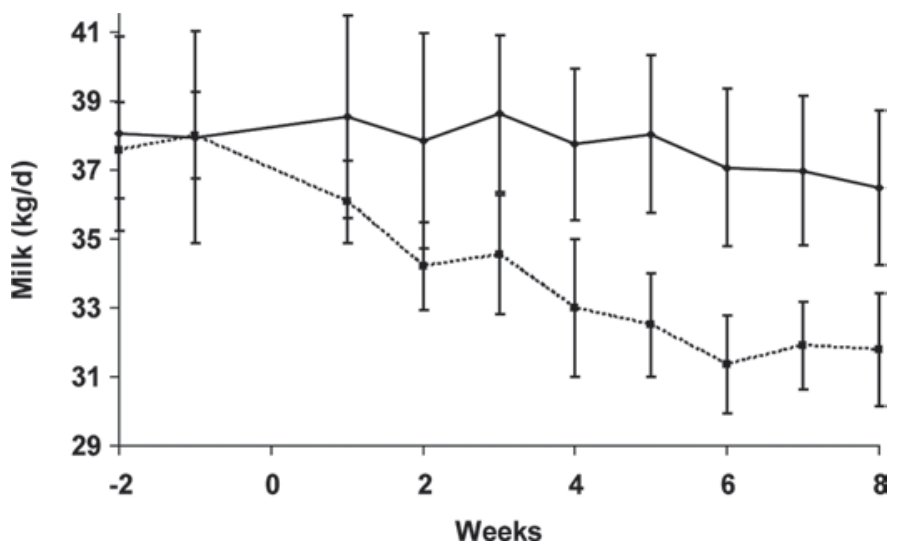

Figure 1. Milk production of dairy cows injected with water $(-\bullet ; \mathrm{n}=4)$ or quinagolide $(--\square--; 1 \mathrm{mg} / \mathrm{d} ; \mathrm{n}=5)$ for 8 wk Quinagolide significantly reduced milk production $(P<0.05)$. Data are presented as least squares means \pm SEM. 


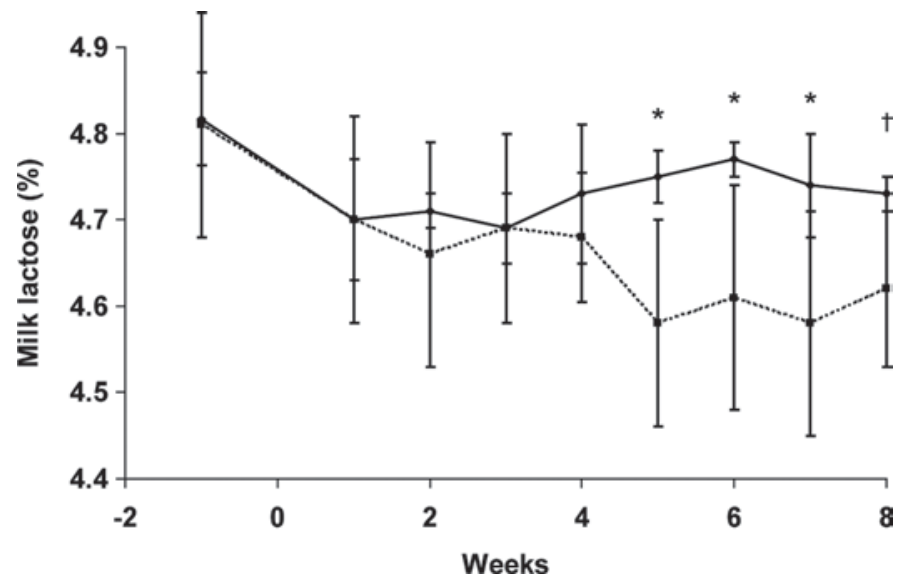

Figure 2. Lactose concentration in milk from dairy cows injected with water $(-\bullet ; \mathrm{n}=4)$ or quinagolide $(-----; \mathrm{n}=5)$ for 8 wk Quinagolide significantly reduced milk lactose concentration in wk 5 , $6,7\left({ }^{*} P<0.05\right)$ and $8(\dagger P<0.1)$. Data presented are least squares means \pm SEM.

treated cows, respectively. However, the cows in both groups gained weight, and no treatment effect on BW was observed (data not shown). Blood concentrations of NEFA, glucose, and urea averaged $152 \pm 28$ and 176 $\pm 24 \mu \mathrm{mol} / \mathrm{L} ; 658 \pm 1$ and $674 \pm 1 \mathrm{mg} / \mathrm{L}$; and $226 \pm$ 12 and $238 \pm 11 \mathrm{mg} / \mathrm{L}$ for the control and quinagolidetreated cows, respectively. They were not affected by treatment.

Milking-induced oxytocin release was monitored after 1 wk of treatment and was not affected by treatment $(P$ $>0.15)$. For the control and quinagolide-treated cows, respectively, the amount of oxytocin that was released averaged $520 \pm 78$ and $545 \pm 107 \mathrm{pg} / \mathrm{mL}$ per minute, and the maximum concentration that was reached averaged $106 \pm 37$ and $116 \pm 34 \mathrm{pg} / \mathrm{mL}$.

Plasma concentration of IGF-1 increased during the treatment period $(P<0.01)$ but was not affected by treatment, averaging $110 \pm 10$ and $124 \pm 9 \mathrm{ng} / \mathrm{mL}$ for the control and quinagolide-treated cows, respectively. Similarly, plasma concentrations of leptin and STC-1 increased slightly over time $(P<0.05)$ but were not affected by treatment, averaging $2.5 \pm 0.1$ and $2.4 \pm$
$0.1 \mathrm{ng} / \mathrm{mL}$ (leptin) and $2.66 \pm 0.06$ and $2.65 \pm 0.05 \mathrm{ng} /$ $\mathrm{mL}$ (STC-1) for the control and quinagolide-treated cows, respectively. Milk concentration of STC-1 was not affected by time or the treatment, averaging 0.91 \pm 0.18 and $1.01 \pm 0.15 \mathrm{ng} / \mathrm{mL}$ for the control and quinagolide-treated cows, respectively.

Mammary tight-junction patency was monitored by analyzing blood lactose and milk BSA concentrations. Blood lactose was not affected by treatment, averaging $23.0 \pm 3.2$ and $24.2 \pm 2.9 \mathrm{mg} / \mathrm{L}$ for the control and quinagolide-treated cows, respectively. Accordingly, BSA concentration was lower than the detection limit $(0.1 \mathrm{mg} / \mathrm{mL})$ in the milk samples of $2 \times$ udder half for both control and quinagolide-treated cows, indicating no opening of the tight junctions (data not shown).

Gelatin zymography showed the presence of proteolytic activity at the apparent molecular weights of $107 \mathrm{kDa}$ in all the milk samples and at $60 \mathrm{kDa}$ in $60 \%$ of the samples. The two proteolytic bands were not affected by time or treatment (data not shown).

Correlations between endocrine parameters and milk production were calculated. The highest correlation coefficients were obtained with the amounts (areas under the curves) and peak values of milking-induced PRL release (Table 2). Interestingly, the coefficients were similar in the control and quinagolide-treated cows. No significant correlations were found between IGF-1 or STC-1 concentrations and milk production (data not shown).

Differential milking resulted in a reduction in milk production in the udder half that was milked $1 \times(P<$ 0.001 ; Figure 3$)$. The inhibitory effect of quinagolide was maintained in the udder half that was milked $2 \times(P<0.05)$ but was lost in the half milked $1 \times$. Similarly, the inhibitory effects of quinagolide on milk protein and fat yields were maintained in the udder half that was milked $2 \times(P<0.05$; Table 3$)$ but not in the half milked $1 \times$. Reducing the milking frequency to $1 \times$ caused increases in milk fat contents as well as in matrix metalloproteinase (MMP)-2 and MMP-9 activity $(P<0.05$; Table 3$)$. Milk BSA content were below the detection limit for $2 \times$ quarters but averaged 0.28

Table 2. Correlation between milking-induced prolactin release in blood and milk production ${ }^{1}$

\begin{tabular}{|c|c|c|c|c|c|c|}
\hline \multirow[b]{2}{*}{ Item $^{2}$} & \multicolumn{2}{|c|}{ All animals } & \multicolumn{2}{|c|}{ Control } & \multicolumn{2}{|c|}{ Quinagolide } \\
\hline & $\mathrm{R}$ & $P$-value & $\mathrm{R}$ & $P$-value & $\mathrm{R}$ & $P$-value \\
\hline AUC & 0.57 & 0.001 & 0.64 & 0.01 & 0.61 & 0.005 \\
\hline Peak & 0.56 & 0.001 & 0.61 & 0.02 & 0.64 & 0.005 \\
\hline
\end{tabular}


Table 3. Effect of the injection of water (control; $\mathrm{n}=4)$ or quinagolide $(1 \mathrm{mg} / \mathrm{d} ; \mathrm{n}=5)$ and differential milking [one udder half milked once a day $(1 \times)$ and the other milked twice a day $(2 \times)]$ on milk composition and gelatinase activity in dairy cows

\begin{tabular}{|c|c|c|c|c|c|c|c|c|c|}
\hline \multirow[b]{2}{*}{ Item } & \multicolumn{2}{|c|}{ Control } & \multicolumn{2}{|c|}{ Quinagolide } & \multicolumn{5}{|c|}{$P$-value ${ }^{1}$} \\
\hline & $1 \times$ & $2 \times$ & $1 \times$ & $2 \times$ & MF & Trt & Trt $\times$ MF & $\operatorname{Trt}(1 \times)$ & $\operatorname{Trt}(2 \times)$ \\
\hline Fat $(\%)$ & 4.74 & 4.17 & 4.50 & 4.28 & 0.03 & $\mathrm{NS}^{2}$ & NS & NS & NS \\
\hline Protein (\%) & 3.37 & 3.22 & 3.41 & 3.36 & 0.02 & NS & 0.16 & NS & NS \\
\hline Protein $(\mathrm{kg} / \mathrm{d})$ & 0.38 & 0.62 & 0.37 & 0.52 & 0.001 & 0.06 & 0.12 & NS & 0.03 \\
\hline MMP-2 $2^{3,4}$ & 60.8 & 6.1 & 60.8 & 8.6 & 0.02 & $\mathrm{NS}$ & NS & NS & NS \\
\hline
\end{tabular}

${ }^{1} \mathrm{MF}=$ milking frequency; $\operatorname{Trt}=$ treatment; $\operatorname{Trt}(1 \times)$ or $\operatorname{Trt}(2 \times)=$ effect of quinagolide treatment in the udder half that was milked once a day or twice a day.

${ }^{2} P>0.20$.

${ }^{3} \mathrm{MMP}=$ matrix metalloproteinase.

${ }^{4}$ Proteolytic activity (integrated density values $\times 10^{-3}$ ) at an apparent molecular weight of $60 \mathrm{kDa}$ on a gelatin zymogram.

${ }^{5}$ Proteolytic activity (integrated density values $\times 10^{-3}$ ) at an apparent molecular weight of $107 \mathrm{kDa}$ on a gelatin zymogram.

\pm and $0.21 \mathrm{mg} / \mathrm{mL}$ in $1 \times$ quarters for the control and quinagolide-treated cows, respectively.

\section{DISCUSSION}

In this experiment, we observed that the dopamine D2 receptor agonist quinagolide inhibited milking-induced PRL release in lactating cows. Although already used in humans for this purpose, quinagolide had never been tested in cows. The main physiological control of PRL secretion is exerted by the inhibitory action of dopamine on the lactotrophs of the anterior pituitary (Torre and Falorni, 2007). Dopamine is secreted in the hypothalamus through the tuberoinfundibular dopamine pathway and reaches the pituitary through

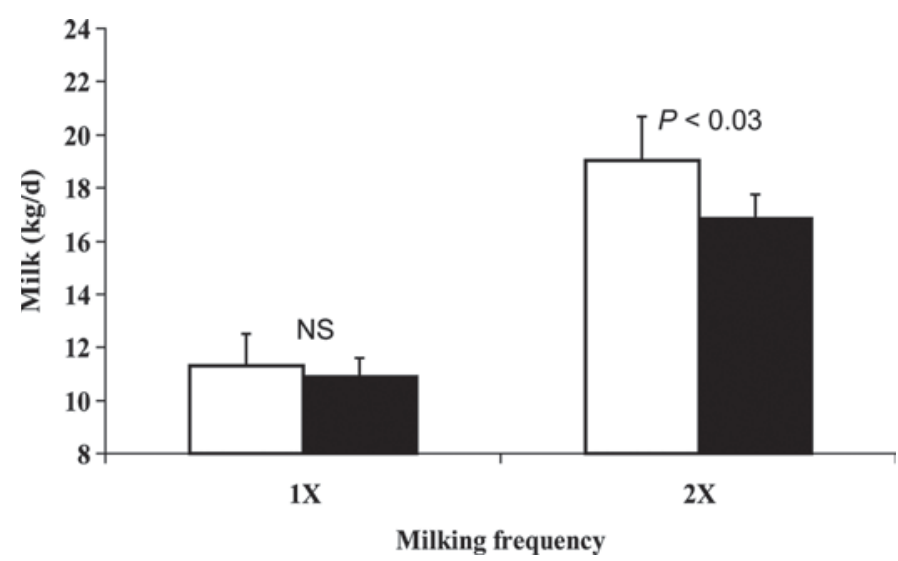

Figure 3. Effect of injecting water (white bars; $n=4$ ) or quinagolide (black bars; $1 \mathrm{mg} / \mathrm{d} ; \mathrm{n}=5$ ) and differential milking [one udder half milked once a day $(1 \times)$ and the other milked twice a day $(2 \times)]$ on milk production of dairy cows. The udder half that was milked $1 \times$ produced less milk than the udder half milked $2 \times(P<0.001)$. The inhibitory effect of quinagolide was maintained in the udder half that was milked $2 \times(P<0.05)$ but lost in the half milked $1 \times(P>0.15)$. Data are presented as least squares means \pm SEM. a portal vascular system. It has been proposed that suckling reduces the activity of the neurons in the tuberoinfundibular dopamine pathway, enabling the release of PRL into the bloodstream (Li et al., 1999). Accordingly, administration of the dopamine antagonist fluphenazine to lactating cows has induced PRL release with a magnitude comparable to that induced by milking (Ahmadzadeh et al., 2006).

Quinagolide did not completely prevent milkinginduced PRL release. The dose used in this study $(1 \mathrm{mg} / \mathrm{d})$ was equivalent, on a BW basis, to the dose used to normalize PRL in hyperprolactinemic women $(0.075 \mathrm{mg} / \mathrm{d}$; Barlier and Jaquet, 2006). With a halflife of $22 \mathrm{~h}$, quinagolide is administered once a day in women (Barlier and Jaquet, 2006). In the present study, the cows were injected at $1000 \mathrm{~h}$ and PRL concentration was evaluated at milking the following morning (about $21 \mathrm{~h}$ later). If the half-life in cows is in the same range as in humans, the circulating concentration at that time would already have been less than half of its maximum. Therefore, it is likely that inhibition was greater at the evening milking. Accordingly, greater inhibition of milking-induced PRL release was observed when cows were also injected after the evening milking (Lollivier et al., 2009).

The administration of quinagolide reduced milk production and yield of milk components. The effect of another dopamine agonist, bromocriptine, on milk production was tested previously in dairy ruminants. In their first experiment, Karg et al. (1972) injected 2 cows with increasing doses (20 to $160 \mathrm{mg}$ ) of bromocriptine for $3 \mathrm{~d}$ and observed an inhibition of PRL without any effect on milk production. Smith et al. (1974) treated 5 cows with $80 \mathrm{mg}$ of bromocriptine for $2 \mathrm{~d}$ without affecting milk production. In their second experiment, however, Karg et al. (1972) injected 2 cows for $7 \mathrm{~d}(5 \mathrm{~d}$ at $150 \mathrm{mg}$ followed by $2 \mathrm{~d}$ at $75 \mathrm{mg}$ ) and reported a 10 
to $20 \%$ decline in milk production. In goats, an early study did not report an effect of bromocriptine on milk yield (Hart, 1973), whereas a subsequent study reported a $21 \%$ decrease in milk production after $8 \mathrm{~d}$ (Knight et al., 1990). The inconsistent effects of bromocriptine on milk production seen in earlier experiments were probably related to the short period of administration and the very small number of experimental animals.

In the present study, milk production was correlated with the amount of PRL released at milking, and this relationship was maintained within each treatment group. This correlation between milking-induced PRL release and milk production, previously reported by Koprowski and Tucker (1973), indicates that the effect of quinagolide on milk production is likely to be mediated by PRL inhibition. The classical way to demonstrate the action of a hormone is to remove its source, observe the changes induced, and try to restore the function by hormone replacement. In a previous study, hypophysectomy of lactating goats caused a sharp decline in milk production that required PRL and other hormones to be restored. Once milk production was back to normal, however, the PRL treatment could be discontinued without milk production decreasing again (Cowie et al., 1964). The logical conclusion of that experiment was that PRL is lactogenic but not galactopoietic in goats. However, the goats were given a large dose $(12.5 \mathrm{mg} / \mathrm{d})$ of bovine growth hormone, and its removal depressed milk production (Cowie et al., 1964). This growth hormone was pituitary-derived and might have been contaminated with PRL as reported by Skarda et al. (1982). Plaut et al. (1987) injected 8 cows for $14 \mathrm{~d}$ with $120 \mathrm{mg}$ of PRL without affecting milk production. Although the injections increased plasma PRL 2- to 5 -fold, they considerably reduced the milking-induced release of PRL. Conversely, the injection of a much smaller dose of PRL $(1 \mu \mathrm{g} / \mathrm{kg}$ of BW) twice a day for the first 3 wk of lactation increased milk production (Wall et al., 2006). In goats, recombinant PRL injections increased milk yield by over $10 \%$, an increase that was comparable and additive to that elicited by growth hormone (Flint and Knight, 1997). Further evidence of the galactopoietic action of PRL is provided by the fact that a long-day photoperiod was found to increase PRL concentration and milk production (Bilodeau et al., 1989), whereas administration of melatonin for $12 \mathrm{wk}$ decreased PRL and milk production (Auldist et al., 2007). In all, a good body of evidence now exists indicating that PRL is galactopoietic in dairy ruminants.

The effect of the treatment in the present study was modulated by milking frequency, with the inhibitory effect of quinagolide lost in the udder half that was milked $1 \times$. In goats, a unilateral increase in milking frequency increased the milk response to PRL admin- istration (Knight, 1993). McKinnon et al. (1988) observed that increasing the milking frequency increased the PRL-binding capacity of the mammary gland. Accordingly, in cows milked differentially (one udder half milked $1 \times$ and the other $3 \times$ ), it was observed that the gene expression of long and short isoforms of PRL receptors was higher in the glands milked more frequently (Bernier-Dodier et al., 2010). That suggests that another important determinant of PRL action is mammary tissue responsiveness, a conclusion that is further supported by the fact that a short-day photoperiod during the dry period was found to increase both the expression of PRL receptors and subsequent milk production (Auchtung et al., 2005). Nevertheless, it is also possible that milk accumulation and tight junction disruption induced by $1 \times$ milking may have masked the treatment-induced responses.

A decrease in feed intake was observed in the quinagolide-treated cows. The injection of female rats with bovine PRL increased feed intake and BW gain (Byatt et al., 1993). The suckling stimulus activates neuropeptide $\mathrm{Y}$ neurons in the dorsomedial nucleus of the hypothalamus, an effect that is reduced by bromocriptine treatment (Li et al., 1999). Although based on results from other species, one study proposed that neuropeptide $\mathrm{Y}$ plays an important role in the increase in feed intake in early lactation (Ingvartsen and Andersen, 2000). It is therefore possible that inhibition of PRL by quinagolide is responsible for the reduction in feed intake. The reduced feed intake did not affect BW gain or blood metabolite concentrations and therefore probably played a minor role in the reduction of milk production.

Feuermann et al. (2006) proposed that PRL affects leptin secretion by the mammary fat pad, which, in turn, increases the lactogenic action of PRL on mammary epithelial cells. In the present study, the circulating leptin concentration was not affected by the quinagolide treatment. In the lactating bovine mammary gland, the mammary fat pad is small and not in direct contact with the epithelium, making the diffusion of a factor from the fat pad to the epithelial tissue unlikely. Therefore, the absence of any effect of the PRL inhibitor on the blood leptin concentration does not support the proposal of Feuermann et al. (2006).

Milk concentration of STC-1 was not affected by quinagolide. Stanniocalcin-1 is a hormone that was first discovered in fish and recently in mammals (Wagner et al., 1995). In fishes, PRL and STC-1 have opposing actions on calcium homeostasis (Flik et al., 1994). In previous experiments where milk production was reduced by injecting estrogen (Delbecchi et al., 2005), by unilaterally stopping milking (Tremblay et al., 2009), or by decreasing milking frequency (Bernier-Dodier et 
al., 2010), increased STC-1 in milk was observed. In those experiments, however, indicators of active involution were also upregulated, suggesting a link between these STC-1 and involution. In the present experiment, those indicators were not affected by quinagolide, and that probably explains why STC-1 was not affected.

Moderate gelatinase activity was detected in milk. According to Raulo et al. (2002), the 107-kDa band corresponds to MMP-9 and the $60-\mathrm{kDa}$ band corresponds to MMP-2. These activities have been shown to increase in milk of the involuting gland during once-a-day milking (Bernier-Dodier et al., 2010), late lactation (Miller et al., 2006), and milk stasis (Tremblay et al., 2009). In this experiment, MMP activities were increased by $1 \times$ milking but not by quinagolide. Therefore, it is unlikely that quinagolide treatment increased the remodeling of the mammary tissue via metalloproteinase activity induction.

In conclusion, the data presented here support the hypothesis that PRL is galactopoietic in dairy cows. The hormone appears to directly affect the mammary gland, but the response to PRL appears to be modulated at the mammary gland level by milking frequency.

\section{ACKNOWLEDGMENTS}

The authors thank P. Lamberton and the physio team at Méjusseaume for taking care of the cows and helping with the blood sampling and injections. The authors are also grateful to A. Brasseur, L. Finot, N. Huchet, J. Portanguen, M. Vérité, S. Wiart-Letort, S. Marion (Institut national de la recherche agronomique, INRA) and G. Tremblay (Agriculture and Agri-Food Canada, Sherbrooke) for providing technical assistance and to L. Delaby (INRA) for formulating the ration. This research was financially supported by INRA and Agriculture and Agri-Food Canada.

\section{REFERENCES}

Accorsi, P. A., B. Pacioni, C. Pezzi, M. Forni, D. J. Flint, and E. Seren. 2002. Role of prolactin, growth hormone and insulin-like growth factor 1 in mammary gland involution in the dairy cow. J. Dairy Sci. 85:507-513.

Ahmadzadeh, A., M. A. Barnes, F. C. Gwazdauskas, and R. M. Akers. 2006. Dopamine antagonist alters serum cortisol and prolactin secretion in lactating Holstein cows. J. Dairy Sci. 89:2051-2055.

Akers, R. M. 2002. Lactation and the Mammary Gland. Iowa State Press, Ames.

Akers, R. M., and A. M. Lefcourt. 1983. Teat stimulation-induced prolactin release in non-pregnant and pregnant Holstein heifers. J. Endocrinol. 96:433-442.

Auchtung, T. L., A. G. Rius, P. E. Kendall, T. B. McFadden, and G. E. Dahl. 2005. Effects of photoperiod during the dry period on prolactin, prolactin receptor, and milk production of dairy cows. J. Dairy Sci. 88:121-127.

Auldist, M. J., S. A. Turner, C. D. McMahon, and C. G. Prosser. 2007. Effects of melatonin on the yield and composition of milk from grazing dairy cows in New Zealand. J. Dairy Res. 74:52-57.
Barlier, A., and P. Jaquet. 2006. Quinagolide-a valuable treatment option for hyperprolactinaemia. Eur. J. Endocrinol. 154:187-195.

Bernier-Dodier, P., L. Delbecchi, G. F. Wagner, B. G. Talbot, and P. Lacasse. 2010. Effect of milking frequency on lactation persistency and mammary gland remodeling in mid-lactation cows. J. Dairy Sci. 93:555-564.

Bilodeau, P. P., D. Petitclerc, N. St Pierre, G. Pelletier, and G. J. St Laurent. 1989. Effects of photoperiod and pair-feeding on lactation of cows fed corn or barley grain in total mixed rations. J. Dairy Sci. 72:2999-3005.

Brownell, J. 1996. Quinagolide (Norprolac): A novel non-ergot prolactin inhibitor. Drugs Today (Barc) 32(Suppl. B):1-31.

Brownell, J. 1998. Quinagolide in hyperprolactinaemia. Rev. Contemp. Pharmacother. 9:1-75.

Byatt, J. C., N. R. Staten, W. J. Salsgiver, J. G. Kostelc, and R. J. Collier. 1993. Stimulation of food intake and weight gain in mature female rats by bovine prolactin and bovine growth hormone. Am. J. Physiol. 264:E986-E992.

Cowie, A. T., G. S. Knaggs, and J. S. Tindal. 1964. Complete restoration of lactation in the goat after hypophysectomy. J. Endocrinol. 28:267-279.

De Niu, P., D. P. Radman, E. M. Jaworski, H. Deol, R. Gentz, J. $\mathrm{Su}, \mathrm{H}$. S. Olsen, and G. F. Wagner. 2000. Development of a human stanniocalcin radioimmunoassay: Serum and tissue hormone levels and pharmacokinetics in the rat. Mol. Cell. Endocrinol. 162:131-144.

Delbecchi, L., N. Miller, C. Prud'homme, D. Petitclerc, G. F. Wagner, and P. Lacasse. 2005. 173-Estradiol reduces milk synthesis and increases stanniocalcin gene expression in the mammary gland of lactating cows. Livest. Prod. Sci. 98:57-66.

Ehrhardt, R. A., R. M. Slepetis, J. Siegal-Willott, M. E. Van Amburgh, A. W. Bell, and Y. R. Boisclair. 2000. Development of a specific radioimmunoassay to measure physiological changes of circulating leptin in cattle and sheep. J. Endocrinol. 166:519-528.

Feuermann, Y., S. J. Mabjeesh, L. Niv-Spector, D. Levin, and A. Shamay. 2006. Prolactin affects leptin action in the bovine mammary gland via the mammary fat pad. J. Endocrinol. 191:407413.

Flik, G., F. Rentier-Delrue, and S. E. Wendelaar Bonga. 1994. Calcitropic effects of recombinant prolactins in Oreochromis mossambicus. Am. J. Physiol. 266:R1302-R1308.

Flint, D. J., M. Boutinaud, C. B. Whitelaw, G. J. Allan, and A. F. Kolb. 2006. Prolactin inhibits cell loss and decreases matrix metalloproteinase expression in the involuting mouse mammary gland but fails to prevent cell loss in the mammary glands of mice expressing IGFBP-5 as a mammary transgene. J. Mol. Endocrinol. 36:435-448.

Flint, D. J., and M. Gardner. 1994. Evidence that growth hormone stimulates milk synthesis by direct action on the mammary gland and that prolactin exerts effects on milk secretion by maintenance of mammary deoxyribonucleic acid content and tight junction status. Endocrinology 135:1119-1124.

Flint, D. J., and C. H. Knight. 1997. Interactions of prolactin and growth hormone $(\mathrm{GH})$ in the regulation of mammary gland function and epithelial cell survival. J. Mammary Gland Biol. Neoplasia 2:41-48.

Forsyth, I. A., and P. D. Lee. 1993. Bromocriptine treatment of periparturient goats: Long-term suppression of prolactin and lack of effect on lactation. J. Dairy Res. 60:307-317.

Fuchs, A. R., L. Cubile, M. Y. Dawood, and F. S. Jorgensen. 1984. Release of oxytocin and prolactin by suckling in rabbits throughout lactation. Endocrinology 114:462-469.

Hart, I. C. 1973. Effect of 2-bromo-ergocryptine on milk yield and the level of prolactin and growth hormone in the blood of the goat at milking. J. Endocrinol. 57:179-180.

Hurtaud, C., H. Rulquin, and R. Verite. 1993. Effect of infused volatile fatty acids and caseinate on milk composition and coagulation in dairy cows. J. Dairy Sci. 76:3011-3020.

Ingvartsen, K. L., and J. B. Andersen. 2000. Integration of metabolism and intake regulation: A review focusing on periparturient animals. J. Dairy Sci. 83:1573-1597. 
Karg, H., D. Schams, and V. Reinhardt. 1972. Effects of 2-Br- $\alpha-$ ergocryptine on plasma prolactin level and milk yield in cows. Experientia 28:574-576.

Knight, C. H. 1993. Prolactin revisited. Pages $72-80$ in Yearbook. Hannah Research Institute, Ayr, UK.

Knight, C. H., D. Foran, and C. J. Wilde. 1990. Interaction between autocrine and endocrine control of milk yield: Thrice-daily milking and bromocriptine-treated goats. J. Reprod. Fertil. Abstr. Ser. 5:30.

Kollmann, M. T., M. Locher, F. Hirche, K. Eder, H. H. D. Meyer, and R. M. Bruckmaier. 2008. Effects of tryptophan supplementation on plasma tryptophan and related hormone levels in heifers and dairy cows. Domest. Anim. Endocrinol. 34:14-24.

Koprowski, J. A., and H. A. Tucker. 1973. Serum prolactin during various physiological states and its relationship to milk production in the bovine. Endocrinology 92:1480-1487.

Li, C., P. Chen, and M. S. Smith. 1999. Neuropeptide Y and tuberoinfundibular dopamine activities are altered during lactation: Role of prolactin. Endocrinology 140:118-123.

Lollivier, V., R. M. Bruckmaier, P. Lacasse, and M. Boutinaud. 2009. Effect of the milking-induced prolactin release on galactopoiesis in dairy cows. J. Dairy Sci. 92(Suppl. 1):507. (Abstr.)

Lupoli, B., B. Johansson, K. Uvnas-Moberg, and K. SvennerstenSjaunja. 2001. Effect of suckling on the release of oxytocin, prolactin, cortisol, gastrin, cholecystokinin, somatostatin and insulin in dairy cows and their calves. J. Dairy Res. 68:175-187.

Marnet, P. G., H. Volland, P. Pradelles, J. Grassi, and M. Beaufils. 1994. Subpicogram determination of oxytocin by an enzyme immunoassay using acetylcholinesterase as label. J. Immunoassay 15:35-53.

McKinnon, J., C. H. Knight, D. J. Flint, and C. J. Wilde. 1988. Effect of milking frequency and efficiency on goat mammary prolactin receptor number. J. Endocrinol. 119(Suppl.):116.

Miller, N., L. Delbecchi, D. Petitclerc, G. F. Wagner, B. G. Talbot, and P. Lacasse. 2006. Effect of stage of lactation and parity on mammary gland cell renewal. J. Dairy Sci. 89:4669-4677.

Paciga, M., A. J. Watson, G. E. DiMattia, and G. F. Wagner. 2002. Ovarian stanniocalcin is structurally unique in mammals and its production and release are regulated through the luteinizing hormone receptor. Endocrinology 143:3925-3934.
Plaut, K., D. E. Bauman, N. Agergaard, and R. M. Akers. 1987. Effect of exogenous prolactin administration on lactational performance of dairy cows. Domest. Anim. Endocrinol. 4:279-290.

Raulo, S. M., T. Sorsa, T. Tervahartiala, T. Latvanen, E. Pirila, J. Hirvonen, and P. Maisi. 2002. Increase in milk metalloproteinase activity and vascular permeability in bovine endotoxin-induced and naturally occurring Escherichia coli mastitis. Vet. Immunol. Immunopathol. 85:137-145.

Skarda, J., E. Urbanova, S. Becka, L. M. Houdebine, C. Delouis, D. Pichova, J. Picha, and J. Bilek. 1982. Effect of bovine growth hormone on development of goat mammary tissue in organ culture. Endocrinol. Exp. 16:19-31.

Smith, V. G., T. W. Beck, E. M. Convey, and H. A. Tucker. 1974. Bovine serum prolactin, growth hormone, cortisol and milk yield after ergocryptine. Neuroendocrinology 15:172-181.

Taylor, J. C., and M. Peaker. 1975. Effects of bromocriptine on milk secretion in the rabbit. J. Endocrinol. 67:313-314.

Torre, D. L., and A. Falorni. 2007. Pharmacological causes of hyperprolactinemia. Ther Clin. Risk Manag. 3:929-951.

Travers, M. T., M. C. Barber, E. Tonner, L. Quarrie, C. J. Wilde, and D. J. Flint. 1996. The role of prolactin and growth hormone in the regulation of casein gene expression and mammary cell survival: Relationships to milk synthesis and secretion. Endocrinology $137: 1530-1539$.

Tremblay, G., P. Bernier-Dodier, L. Delbecchi, G. F. Wagner, B. G. Talbot, and P. Lacasse. 2009. Local control of mammary involution: Is stanniocalcin-1 involved? J. Dairy Sci. 92:1998-2006.

Vicari, T., J. J. van den Borne, W. J. Gerrits, Y. Zbinden, and J. W. Blum. 2008. Postprandial blood hormone and metabolite concentrations influenced by feeding frequency and feeding level in veal calves. Domest. Anim. Endocrinol. 34:74-88.

Wagner, G. F., C. C. Guiraudon, C. Milliken, and D. H. Copp. 1995 Immunological and biological evidence for a stanniocalcin-like hormone in human kidney. Proc. Natl. Acad. Sci. USA 92:18711875.

Wall, E. H., H. M. Crawford, S. E. Ellis, G. E. Dahl, and T. B. McFadden. 2006. Mammary response to exogenous prolactin or frequent milking during early lactation in dairy cows. J. Dairy Sci. 89:4640-4648 